\title{
A study of packing parameters that influence the fresh properties of self-compacting concrete
}

\section{(Um estudo de parâmetros de empacotamento que influenciam as propriedades no estado fresco do concreto autoadensável)}

\author{
C. V. A. de Melo ${ }^{1 *}$, P. C. C. Gomes ${ }^{2}$ K. A. M. Moraes ${ }^{2}$ \\ ${ }^{1}$ Universidade Federal de Alagoas, Materials Doctoral Program, LEMA, Maceió, Brazil \\ ${ }^{2}$ Universidade Federal de Alagoas, Civil Engineering, LEMA, Maceió, Brazil
}

\begin{abstract}
Some known self-compacting concrete (SCC) mix-designs are based on the lowest void content as a purpose of an ideal packing. However, a composition with a lower void content is not a guarantee of good synergy between the largest and smallest grain in the fresh state. The purpose of this study was to identify and evaluate different packing parameters in the aggregates gradations that influence on the self-compactability. Nine aggregates combinations ( 4 binaries, 4 ternaries and 1 quaternary) were used for determination of nine gradations. Tests as slump-flow, L-box and V-funnel were used. The distribution coefficient (q) was determined by the Alfred model. The results showed that not all values of q (between 0.201 and 0.253 ) attended the values given for SCC, and the gradations with the lowest difference among the coarse and fine particles, higher void content, continuous distributions and $50 \%$ of coarse aggregates had better performance.
\end{abstract}

Keywords: aggregate gradations, void content, packing parameters, self-compactability.

Resumo

Alguns métodos de dosagem de concreto autoadensável (CAA) conhecidos são baseados no menor índice de vazios como uma proposta de empacotamento ideal. Contudo, uma composição com um menor teor de vazios não é garantia de uma boa sinergia entre os grãos maiores e menores no estado fresco. $O$ objetivo deste estudo foi identificar e avaliar diferentes parâmetros de empacotamento nas graduações de agregados que influenciam na autoadensabilidade. Nove combinações de agregados (4 binárias, 4 ternárias e 1 quaternária) foram usadas para determinação de nove graduações. Ensaios como slump-flow, caixa-L e funil-V foram usados. O coeficiente de distribuição (q) foi determinado no modelo de Alfred. Os resultados mostraram que nem todos os valores de q (entre 0,201 e 0,253) atenderam aos indicados para o CAA, e que as graduações com menor diferença entre partículas graúdas e miúdas, maior teor de vazios, distribuição contínua e 50\% de agregado graúdo tiveram melhor desempenho.

Palavras-chave: graduações de agregados, índice de vazios, parâmetros de empacotamento, concreto autoadensável.

\section{INTRODUCTION}

Developed on the decade of the 1980s in Japan, self-compacting concrete (SCC) has been the subject of numerous studies [1-5]. Being a special concrete, several mix-design methods have been proposed $[2,3$, 5-9], highlighting, as basic difference to the dosages for conventional concrete, a higher consumption of paste, smaller size of coarse aggregate and a lower ratio of fine aggregate to coarse aggregate. Including the rheology of SCC, it has been specified a moderate plastic viscosity and a low yield shear stress that have the influence of particle packing, the content of fine materials and the problem of the high coarse aggregate volume in the stability of the concrete $[1,7]$. These differences can be better observed

*cassiamelo@ctec.ufal.br

(D) https://orcid.org/0000-0002-8541-5998 through the reference parameters (RPs) recommended for compositions of SCC. Observing the RPs in Table I, it is noted that SCC presents a smaller coarse aggregate volume, a larger fine aggregate volume, greater fines mass and, consequently, higher paste volume. This high paste volume ensures the self-compactability of the granular particle system, which is directly proportional to the grains dispersion. However, it represents a high cost for the concrete, because the most expensive components of the mixture are the cement and chemical admixture [15], in addition to increasing the possibility of a higher shrinkage [16]. The SCC compositions are evaluated regarding the self-compactability properties, through tests of slump-flow, L-box and V-funnel [2, 4, 8, 10, 11]. Several standards around the world have established these tests and others [17, 18]. In Brazil, NBR 15823-1:2017 [17] highlights the classification, control and acceptance of the selfcompacting concrete, which must be met in accordance 
with the test methods presented in the standards NBR 15823-2:2017 [19], NBR 15823-4:2017 [20] and 158235:2017 [21].

Table I - Reference parameters for SCC mixtures $\left(1 \mathrm{~m}^{3}\right)$ [3-5, 7-14].

[Tabela I - Parâmetros de referência de misturas de CAA $\left.\left(1 \mathrm{~m}^{3}\right)[3-5,7-14].\right]$

\begin{tabular}{cc}
\hline Parameter & Interval \\
\hline Cement $\left(\mathrm{kg} / \mathrm{m}^{3}\right)$ & $200-475$ \\
Fines' mass $\left(\mathrm{kg} / \mathrm{m}^{3}\right)$ & $400-687$
\end{tabular}

Paste content per cubic meter of concrete

Coarse aggregate mass $\left(\mathrm{kg} / \mathrm{m}^{3}\right)$

Fine aggregate mass $\left(\mathrm{kg} / \mathrm{m}^{3}\right)$

710-900

Coarse aggregate volume $\left(\mathrm{m}^{3}\right)$

Coarse aggregate volume/ total aggregate volume $\left(\mathrm{m}^{3} / \mathrm{m}^{3}\right)$

Fine aggregate volume/t otal aggregate volume $\left(\mathrm{m}^{3} / \mathrm{m}^{3}\right)$

Fine aggregate volume/ mortar volume $\left(\mathrm{m}^{3} / \mathrm{m}^{3}\right)$

Fines content, $<2.50 \mathrm{~mm}\left(\% / \mathrm{m}^{3}\right)$

It is common, in some mix-design methods, to assume the SCC as a material of two phases: the paste (or matrix) and the aggregates [11]. In the first phase, the study of the fluid components predominates (water to cement, w/c, ratio, chemical and mineral admixture dosage), and the second is the aggregate composition that is determined. For this phase, some experimental methods and numerical models have been applied, based on the particle packing principle. The experimental method proposed by O'Reilly [22] consists in obtaining the optimum ratio of fine aggregates to coarse aggregates, through the highest unit weight and the lowest void content, also called intergranular porosity [15], resulting in greater compactness and lower cement consumption. The particularities considered in this method are the shape factor, particle size distribution, texture, being based in particle packing. Besides, the procedure of this method allows its application irrespective of the nature and origin of the aggregates [22]. It is also understood that the wall effect takes into account both the size and shape of the grains, being the mode of interaction that occurs between the surfaces of larger and smaller particles. The method has been used by several researchers in the determination of aggregate compositions for SCC and for other special concretes [4,6,10-14,23-26], highlighting the predominance of compositions whose ratios of fine aggregate to coarse aggregate are around $50 \%[2,5,23,24,27]$. These ratios and recommendation of the decrease in the coarse aggregate size lead to a greater approximation between the coarse and fine grains, which favors the packing of composition for SCC and has been recommended by several methods.
However, the porosity of a granular mixture becomes larger, i.e., the packing tends to be reduced when increasing the concentration of particles of closer sizes, especially if they are irregular [28]. The contact between the irregular particles can lead to a lower packing density, due to the greater angularity of the grains. That way, the particle arrangement becomes impaired, making it difficult to reach the lowest void content, being considered relevant for influencing the rheological properties and hardened state [28-30].

For systems with particles of very different sizes, much smaller particles are sufficient to fill in the gaps left by the larger particles, thus increasing the packing density, without any distortion of the original packing [29]. According to Chateau [29], it is possible to continue filling the existing voids as many times as necessary, until a multimodal mixture is obtained, intending to insert particles of smaller fraction particle size, which occupy exactly the space left by the particles larger than these. Regarding the role of the fractions of smaller size particles, Moosberg-Bustnes et al. [30] are quite emphatic in saying that a greater relative volume of these fractions can contribute with good results of compactness and workability of the concrete. Thus, there is the question of denser packing in aggregates mixtures, obtained with the highest relation of sizes between the largest and smallest particles, in binary mixtures [31]. Being small this relation of sizes, the packing density is reduced due to the effects of block and wall. The wall effects of aggregates of closer sizes or the loosening effects may increase the void content. Thus, it is necessary to study the aggregate combination so that voids can be minimized $[1,7]$. Therefore, when it comes to SCC, the recommendation of approximation of particle sizes can lead to aggregate compositions with larger voids, which lead to a larger paste volume, which may favor the concrete mobility. Other experimental and analytical methods, such as those developed by Fuller-Thompson, Bolomey, Joisel and Faury [32], despite not being applied in the determination of dosage for SCC, also have the principle of ensuring a maximum possible packing, minimizing the void content, by means of reference curves that allow to obtain an ideal grading curve of aggregate compositions, in order to better represent all the particles in the particle size fractions. These models have been the basis for other mathematical models of particle size distribution that have been applied in the determination of SCC compositions in several studies, among them the Alfred model or modified Andersen-Andreasen (A\&A) model [25, 28, 33-36]:

$$
\operatorname{CPFT}(\%)=100\left(\frac{D_{p}^{q}-D_{s}^{q}}{D_{L}^{q}-D_{s}^{q}}\right)
$$

where CPFT is the accumulated percentage of particles below $D_{P}$, which is the size of the coarse particle, $D_{S}$ is the size of the smallest particle, $\mathrm{D}_{\mathrm{L}}$ is the size of the largest particle and q corresponds to the distribution coefficient. For SCC, a proposed mixture turns out to have q-value, from 0.22 to 0.25 , thus incorporating finer particles [12]. Vanderlei [35] also noted that the reduction of the value of the distribution coefficient occurs due to the increased presence of fines in 
SCC, influencing the interaction among the particles. The q-values equal to 0.21 and 0.26 were verified, as well as values lower than 0.28 [25]. Commonly from 0.29 and 0.30 , the q-values apply to concretes compacted by vibration [35, 37]. The distribution coefficient has also been referred to as a parameter of dosage, in view of the interest in obtaining compositions of SCC based on the theory of packing [38]. In this context, this study has as objective to evaluate different aggregate combinations of binary, ternary and quaternary compositions applied in the SCC, seeking to identify the parameters of existing packing and reference in the aggregate compositions, and to verify the influence these in attendance to the recommendations for the SCC mix-design and the self-compactability properties.

\section{MATERIALS AND METHODS}

Aggregates characterization, combination and composition: the characteristics of coarse and fine aggregates used in the preparation of these compositions are presented in Table II. Two types of river sand (fine, F, and medium, M, sand) were used as fine aggregate (Fig. 1a). The crushed limestones with a maximum size of $12.5 \mathrm{~mm}(\mathrm{G} 12)$ and $19 \mathrm{~mm}$ (G19) were used as coarse aggregate to prepare the aggregate compositions (Fig. 1b). The available Portland cement type II F-32 in accordance with the requirements was utilized. The mineral admixture was marble and granite waste (MGW) with a specific gravity of $2.69 \mathrm{~g} / \mathrm{cm}^{3}$ and particles smaller than $150 \mu \mathrm{m}$. Fig. 2 shows the particle size distribution curves of these fine materials obtained by the laser scattering method. High-range water reducing admixture (HRWRA) based on polycarboxylate with a specific gravity of $1.087 \mathrm{~g} / \mathrm{cm}^{3}$ was also utilized.

Table II - Characteristics of aggregates.

[Tabela II - Características dos agregados.]

\begin{tabular}{ccccc}
\hline Property & G12 & G19 & M & F \\
\hline Specific gravity $\left(\mathrm{kg} / \mathrm{m}^{3}\right)$ & 2710 & 2670 & 2630 & 2620 \\
Loose unit weight $\left(\mathrm{kg} / \mathrm{mm}^{3}\right)$ & 1380 & 1420 & 1440 & 1530 \\
Maximum size $(\mathrm{mm})$ & 12.5 & 19.0 & 2.4 & 1.2 \\
Fineness modulus & 6.07 & 6.78 & 2.69 & 1.73 \\
\hline
\end{tabular}

The aggregate granular combinations and compositions, assessed in this study, were obtained from [23]. Altogether there were nine aggregates combinations. The combinations followed the increasing order of the size of samples, in the following way: four binaries (FG12, FG19, MG12, MG19); four ternaries (FMG12,FMG19, FG12G19, MG12G19); and a quaternary (FMG12G19). For each combination, the loose unit weight and the void content were determined according to NBR NM 45:2006 [39], method C, in a loose state. Due to a larger unit weight $(\mathrm{Mu})$ and a lower void rate $\left(\mathrm{I}_{\mathrm{v}}\right)$ for each combination, the aggregate composition was defined according to the method of O'Reilly [22]. It should be emphasized that, due to the experimental procedure carried out for obtaining the final nine compositions of aggregates,
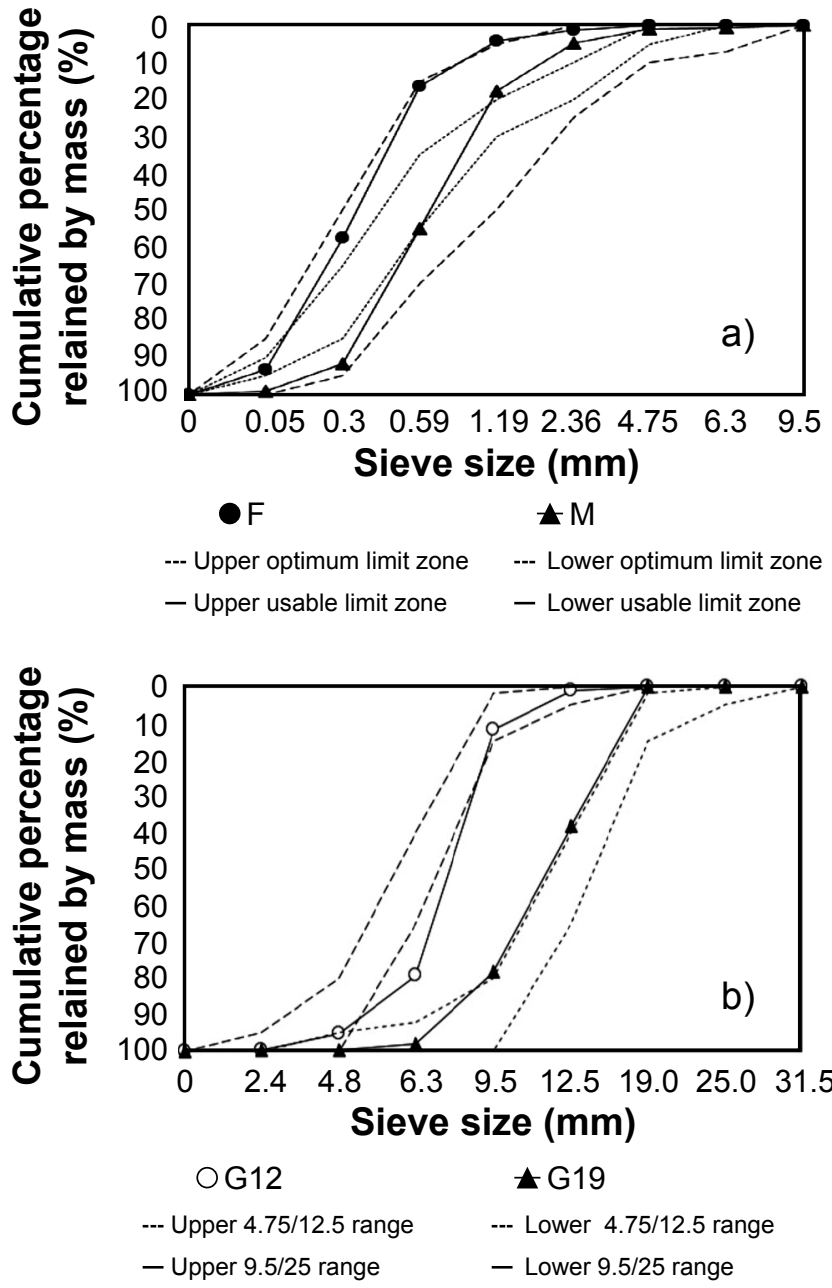

Figure 1: Particle size distribution curves for fine (a) and coarse (b) aggregates.

[Figura 1: Curvas granulométricas de agregados miúdos (a) e graúdos (b).]

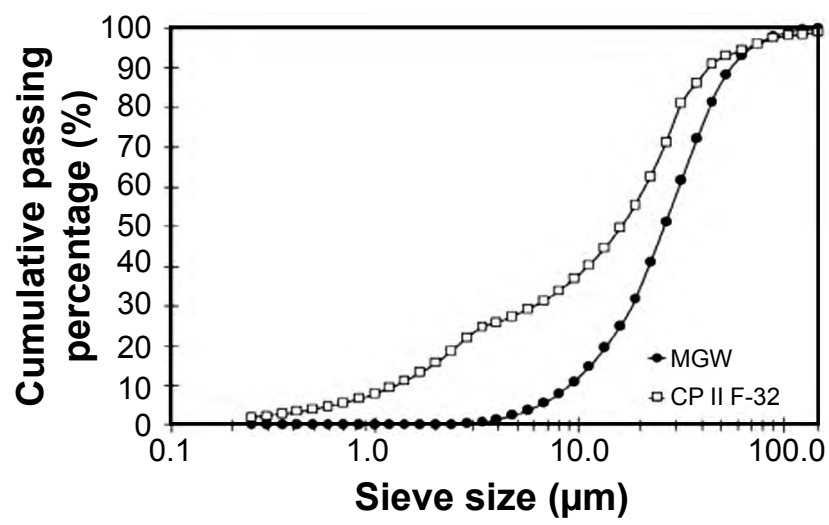

Figure 2: Particle size distribution curves for marble and granite waste and cement CPII F-32.

[Figura 2: Curvas granulométricas do resíduo de beneficiamento de mármore e granito e do cimento CPII F-32.]

the compositions took into consideration the particle size distribution, shape of the grains and the wall effect caused by particle size differences. In this study, these compositions were evaluated in relation to some parameters that influence 
the particle packing: $\mathrm{I}_{\mathrm{v}}$ and the difference between coarse and fine particle sizes. Considering the influence of smaller particles in packing [15, 28-30], the aggregate compositions were presented by means of particle size distribution curves, seeking to obtain a relation regarding the presence of the smallest dimension of aggregates. The different curves of particle size distribution were used for the assessment regarding the continuous or discontinuous polymodal distribution of the compositions. These curves were separated in the following way: compositions with 'G12' and/or 'G19' that contained both ' $\mathrm{F}$ ' and ' $\mathrm{M}$ ', the ones which contained only $\mathrm{F}$ and those that contained only M. Standardized sieves $(19.0,12.5,9.5,6.3,4.75,2.36,1.18,0.60,0.30$ and 0.15 $\mathrm{mm}$ ) were used for particle size distribution analysis with the ratio of 2.

Dosage and properties of SCC: the dosage of SCC was determined for each aggregates composition [23], resulting in nine compositions of SCC. In these compositions, the paste volume was fixed $(40 \%$ in relation to the concrete volume) and its composition, varying only the aggregate compositions. The dosages of SCC were evaluated in relation to the reference parameters (RPs) indicated in indicated in Table I. The self-compactability properties of SCC were determined by slump flow, L-box and V-funnel tests [17] and classified by classes defined in the NBR 15823-1:2017. In the slump flow test, three flow diameters (Df) were measured, two perpendicular and a third, which corresponded to the least favorable diameter, immediately at the end of the flow. The visual stability index (VSI) of slump flow was subjectively determined, depending on the uniformity of the flow diameter, the coarse aggregate distribution throughout the flow and the paste segregation on the edges of the final diameter. In the trial of L-box, the passing ability parameter (HP) of SCC was evaluated among the obstacles (3 steel bars spaced $40 \pm 1 \mathrm{~mm}$ ).

Method of particle packing: the particle packing model (PPM), called Alfred model (or modified A\&A model) [28, 34, 38], was implemented in the program EMMA (Elkem Material Mix Analyzer) [40] and in spreadsheets developed in the software Microsoft Excel. EMMA was used to obtain experimental grading curves of concrete mixtures, without modification of the particle size distribution. For the evaluation of packing theoretical curves (predicted), through spreadsheets in order to assess the dosing parameter $\mathrm{q}$, it was verified initially the approximation of the experimental curve of each mixture of concrete to the corresponding theoretical curve, assuming any value of q. In this program, the dosages of concretes were inserted per cubic meter of concrete, just considering the solid materials (cement, admixtures and aggregates). The packing curves were represented graphically in cumulative percentages passing finer than (CPFT, \%) as ordinate, in arithmetic scale, and depending on the size of particles $\left(\mathrm{D}_{\mathrm{P}}, \mu \mathrm{m}\right)$ as abscissa, in logarithmic scale. For determination of CPFT of these theoretical curves, in addition to the distribution coefficient, the following conditions were provided: fixed sizes $D_{L}$ and $\mathrm{D}_{\mathrm{S}}$ of each experimental mixture; and variable $\mathrm{D}_{\mathrm{P}}$, which was the parameter that depended on the sieve sizes. With the experimental grading curves, exported from EMMA, and the theoretical curve obtained from the spreadsheets, the quadratic error of differences was determined $\left(\mathrm{E}^{2}\right)$ between the experimental and theoretical CPFTs, for each particle size $\left(D_{P}\right)$; finally, the sum of these quadratic differences $\left(\Sigma \mathrm{E}^{2}\right)$ was calculated. In this assessment, it was verified what values of q corresponded to a particular distribution coefficient (q-value) indicated for SCC $(0.21 \leq \mathrm{q} \leq 0.28)$ [ 25 , $28,35,40]$. With the use of linear programming, specifically with the use of the tool 'solver', the objective function $\Sigma \mathrm{E}^{2}$ was minimized, making the values of $D_{L}, D_{s}$ and $q$ informed, and the variables that needed to be changed, returned by the solver and maintained as a solution to the objective function for each concrete composition. Thus, the deviations were optimized and the parameter $\mathrm{q}$ for each mixture was reached. As a result, curves of non-linear adjustment of the PPM and a statistical coefficient of determination $\mathrm{R}^{2}$ were obtained, corresponding to the optimized values of q. Superimposing these curves with experimental grading curves of each composition, it was verified how the experimental data of mixtures behaved with the predicted data. Finally, the distribution coefficients (q-values), generated by the adjustment, indicated which mixtures fit or not the values indicated for self-compacting concrete.

\section{RESULTS AND DISCUSSION}

Aggregate gradations: the final selected aggregate gradations, in a total of nine aggregate compositions, for each combination (binary, ternary and quaternary), were defined by the largest unit weight $(\mathrm{Mu})$ and the lowest void content $\left(\mathrm{I}_{\mathrm{v}}\right)$, Table III. It was observed, in general, that the percentages of coarse aggregates (PCA) ranged from $50 \%$ to $55 \%$, and the fines from $45 \%$ to $50 \%$, regarding the total aggregate content, which was in agreement with those found in the literature $[2,23,24,27]$. The variation found in the $I_{v}$ or intergranular porosity [15] is justified by the different proportions, particle size fractions (particle size) and shape of the grains present in different combinations and compositions. Test results are reported in Table III which show that standard deviations of void content were smaller than $0.5 \%$, indicating that the data tended to be close to the mean void content. It is important to know that the $\mathrm{Mu}$ and $\mathrm{I}_{\mathrm{V}}$ referred to the mean value of three determinations. It was verified that the value of $I_{v}$ varied with the difference in size between the particles of coarse and fine aggregates. The higher this difference, the lower was the $\mathrm{I}_{\mathrm{v}}$; for example, the combination FG19, which had a particle size difference between coarse and fine aggregates larger than the FG12, had $\mathrm{I}_{\mathrm{v}}(27.6 \%)$ lower than $\mathrm{I}_{\mathrm{v}}(30.1 \%)$ of the latter, and both had $\mathrm{I}_{\mathrm{v}}$ lower than the MG12 (34.7\%), which had the smallest particle size difference between coarse and fine aggregates in relation to both. This showed that, when the concentration of approximate sizes of particles or similar increased, the packing became reduced, consequently, increasing the $I_{v}$ [29]. This fact showed that the compositions with the 
Table III - Aggregate gradations and properties; adapted from [23].

[Tabela III - Graduações e propriedades de agregados; adaptado de [23].]

\begin{tabular}{|c|c|c|c|c|c|c|c|}
\hline \multirow{3}{*}{ Combination } & \multicolumn{4}{|c|}{ Aggregate composition (\%) } & \multicolumn{3}{|c|}{ Physical property } \\
\hline & \multicolumn{2}{|c|}{ Fine aggregate } & \multicolumn{2}{|c|}{$\begin{array}{c}\text { Coarse } \\
\text { aggregate }\end{array}$} & \multirow{2}{*}{$\begin{array}{l}\text { Mean void } \\
\text { content } \\
(\%)\end{array}$} & \multirow{2}{*}{$\begin{array}{c}\text { Standard } \\
\text { deviation of void } \\
\text { ontent }(\%)\end{array}$} & \multirow{2}{*}{$\begin{array}{c}\mathrm{Mu} \\
\left(\mathrm{kg} / \mathrm{m}^{3}\right)\end{array}$} \\
\hline & $\mathrm{F}$ & M & G12 & G19 & & & \\
\hline FG12 & 45.0 & - & 55.0 & - & 30.1 & 0.23 & 1866.3 \\
\hline FG19 & 45.0 & - & - & 55.0 & 27.6 & 0.44 & 1917.0 \\
\hline MG12 & - & 50.0 & 50.0 & - & 34.7 & 0.12 & 1743.5 \\
\hline MG19 & - & 45.0 & - & 55.0 & 31.3 & 0.20 & 1822.4 \\
\hline FMG12 & 23.0 & 27.0 & 50.0 & - & 33.6 & 0.38 & 1767.7 \\
\hline FMG19 & 23.0 & 27.0 & - & 50.0 & 30.9 & 0.32 & 1822.9 \\
\hline FG12G19 & 45.0 & - & 25.0 & 30.0 & 31.9 & 0.13 & 1804.5 \\
\hline MG12G19 & - & 40.0 & 27.0 & 33.0 & 32.6 & 0.23 & 1796.3 \\
\hline FMG12G19 & 22.0 & 28.0 & 22.0 & 28.0 & 32.1 & 0.27 & 1803.4 \\
\hline
\end{tabular}

greatest difference in size between particles of coarse and fine aggregates (GDPCF), FG12 (30.1\%), FG19 (27.6\%), FG12G19 (31.9\%), MG19 (31.3\%) and FMG19 (30.9\%), developed a greater filling of the voids, leading to values of $\mathrm{I}_{\mathrm{V}}<32.0 \%$ and consequently a higher composition packing, according to the literature $[29,30]$. In turn, the compositions with a smaller particle size difference between coarse and fine aggregates (SDPCF), MG12 (34.7\%), FMG12 (33.6\%), MG12G19 (32.6\%) and FMG12G19 (32.1\%), had $\mathrm{I}_{\mathrm{v}}$ $>32.0 \%$. Another fact related to compositions of GDPCF, is that the percentage of coarse aggregates (PCA) was 55\%, with the exception of FMG19, which was 50\%, which may have occurred due to the presence of a further fine material ' $M$ ', which reduced the difference in size between the coarse and fine particles and, consequently, reduced the percentage of coarse aggregate. And in the SDPCF, PCA was 50\%, with the exception of MG12G19 of $60 \%$, similar to what occurred with FMG19, only in this case the 'G12' favored the increase in the percentage of all the coarse particles.

It should be noted, also in the compositions with GDPCF, that the presence of ' $F$ ' and the absence of ' $M$ ' and 'G12' favored the lower content of $\mathrm{I}_{\mathrm{V}}$ and larger packing in relation to the compositions with SDPCF. For an assessment of the aggregate gradation in the function of the absence of $\mathrm{M}$ and G12, in Fig. 3 the resultant curves of the particle size distribution of the aggregate compositions are shown, seeking to obtain a relation as to the continuity and discontinuity of these compositions. It is noted in Figs. $3 a$ and $3 b$ that the compositions FMG12, FMG12G19, MG12 and MG12G19 with more open particle size distribution curves and with less expressive low points indicated continuous distributions, whereas those compositions with more expressive low points, which was more closed due to the absence of G12 (FMG19, MG19) and M (FG12, FG19, FG12G19), Fig. $3 \mathrm{c}$, led to a greater tendency to discontinuity. In addition, these curves showed GDPCF characteristics, and the other curves with a tendency to continuity were SDPCF. However,
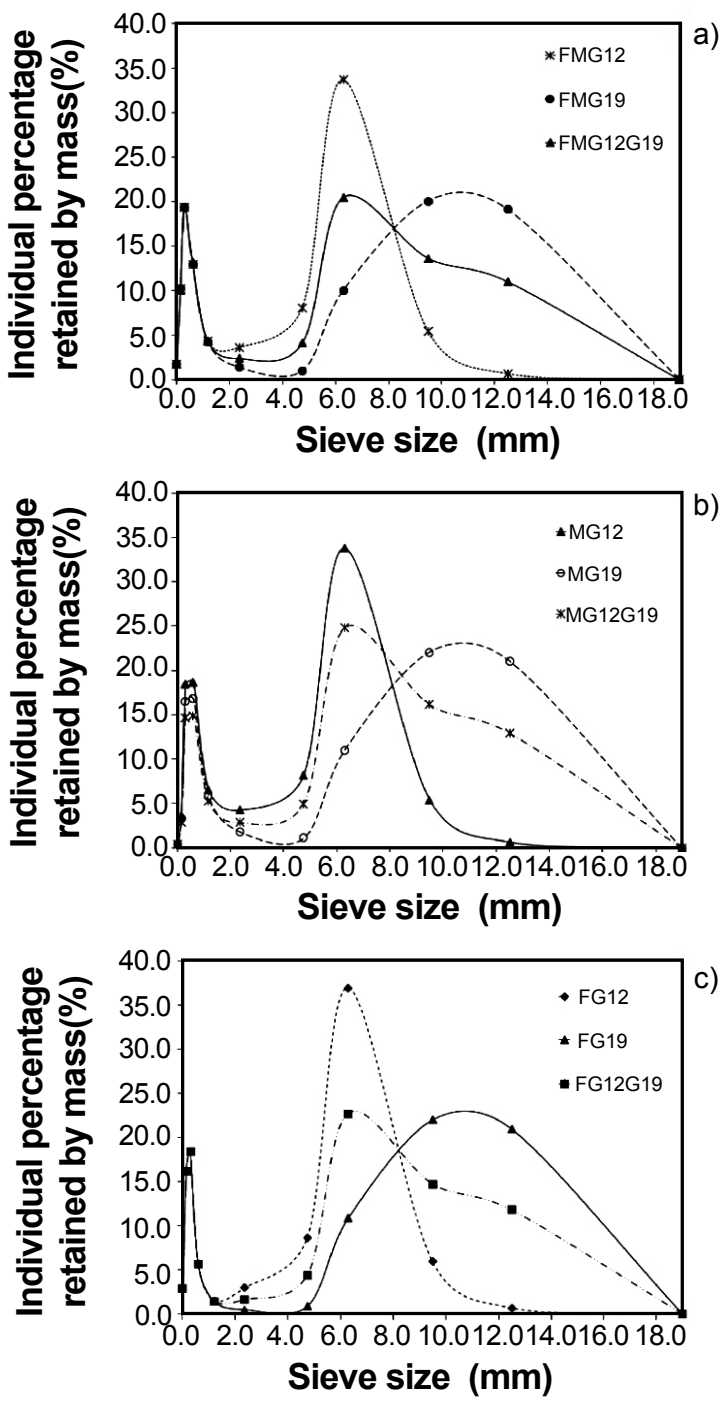

Figure 3: Particle size distributions curves with the fine aggregate combinations: a) F and M; b) M; and c) F.

[Figura 3: Curvas de distribuição granulométrica com as combinações de agregados miúdos: a) F e M; b) M; e c) F.] 
Table IV - Dosage and reference parameters of SCC.

[Tabela IV - Parâmetros de referência e de dosagem de CAA.]

\begin{tabular}{|c|c|c|c|c|c|c|c|c|c|c|}
\hline Parameter & Material & CFG12 & CFG19 & CMG12 & CMG19 & CFMG12 & CFMG19 & CFG12G19 & CMG12G19 & CFMG12G19 \\
\hline \multicolumn{11}{|c|}{ Range of aggregates } \\
\hline \multirow{2}{*}{$\begin{array}{c}\text { Mam } \\
710-900 \\
\left(\mathrm{~kg} / \mathrm{m}^{3}\right)\end{array}$} & Fine sand $(\mathrm{F})$ & 723 & 716 & - & - & 368 & 365 & 717 & - & 351 \\
\hline & Medium sand (M) & - & - & 801 & 717 & 432 & 429 & - & 639 & 446 \\
\hline \multirow{2}{*}{$\begin{array}{c}\text { Mag } \\
750-920 \\
\left(\mathrm{~kg} / \mathrm{m}^{3}\right)\end{array}$} & $\begin{array}{c}\text { Crushed gravel } \\
12.5(\mathrm{G} 12)\end{array}$ & 881 & - & 801 & - & 800 & - & 399 & 432 & 351 \\
\hline & $\begin{array}{c}\text { Crushed gravel } \\
19.0(\mathrm{G} 19)\end{array}$ & - & 873 & - & 874 & - & 794 & 478 & 527 & 446 \\
\hline \multicolumn{11}{|c|}{ Reference parameter (RP) } \\
\hline \multicolumn{2}{|c|}{ Vag/Vat $0.44-0.65\left(\mathrm{~m}^{3} / \mathrm{m}^{3}\right)$} & 0.54 & 0.55 & 0.50 & 0.55 & 0.50 & 0.50 & 0.54 & 0.60 & 0.52 \\
\hline \multicolumn{2}{|c|}{ Vam/Vat $0.35-0.60\left(\mathrm{~m}^{3} / \mathrm{m}^{3}\right)$} & 0.46 & 0.45 & 0.50 & 0.45 & 0.50 & 0.50 & 0.46 & 0.40 & 0.48 \\
\hline \multicolumn{2}{|c|}{$\mathrm{Vag} / \mathrm{Vc} 28-35\left(\% / \mathrm{m}^{3}\right)$} & 32 & 33 & 30 & 33 & 33 & 30 & 33 & 36 & 30 \\
\hline \multicolumn{2}{|c|}{$\operatorname{Vam} / \operatorname{Varg} 40-50\left(\% / \mathrm{m}^{3}\right)$} & 44 & 44 & 47 & 44 & 44 & 43 & 41 & 38 & 46 \\
\hline
\end{tabular}

Note: for each composition of SCC (40\% of paste volume), $400 \mathrm{~kg} / \mathrm{m}^{3}$ cement, $200 \mathrm{~kg} / \mathrm{m}^{3} \mathrm{MGW}$ (marble and granite waste) filler, $200 \mathrm{~kg} / \mathrm{m}^{3}$ water, and $7.97 \mathrm{~kg} / \mathrm{m}^{3}$ admixture were used; Mam-fine aggregate mass; Mag-coarse aggregate mass; Vag-coarse aggregate volume; Vam-fine aggregate volume; Vat-total aggregate volume; Vc-concrete volume; Varg-mortar volume.

when it comes to the aggregate compositions for SCC, it is recommended to reduce both the maximum dimension and the coarse aggregate volume, making them approaching the maximum volume and size of fine aggregates $[4,5,11,14]$. Therefore, there was a tendency, in the formulation of the aggregate composition for the SCC, of an approximation of the grains of coarse and fine aggregates. These trends, according to the analysis of the studied compositions, led to obtaining compositions with a continuous distribution, SDPCF, and consequently higher $I_{v}$, distancing from a maximum packing, due to the intermediate diameter that led to highest void content. Therefore, it contributed to a greater paste volume in the concretes, justifying the high content of this paste in the SCC necessary to reach the selfcompactability requirements.

Composition of SCC: after defining the aggregate compositions (Table III) and fixing the composition and paste volume according to [23], the concrete compositions, ranges of aggregates and reference parameters (RPs) to
SCC, referenced in the literature (Table I), are presented in Table IV. The concretes were named from the aggregate combinations, for example, combination FG12 refers to concrete as CFG12. In general, the dosages of aggregates used in the compositions of SCC (Table IV) complied with the ranges of content of aggregates and the RP indicated to SCC, with the exception of CMG12G19, that presented higher consumption for coarse aggregate, $959 \mathrm{~kg} / \mathrm{m}^{3}$, and inferior for fine aggregate, $639 \mathrm{~kg} / \mathrm{m}^{3}$. The content of fines, although high, $20.2 \%$ in concrete volume, with a mass of $600 \mathrm{~kg} / \mathrm{m}^{3}$, fit in the value specified for SCC. In continuation, these compositions to SCC produced experimentally are analyzed numerically by PPM.

Self-compactability properties: the results of the selfcompactability tests, and the classes that specify the SCC [17], are presented in Table V. It was observed that despite the $\mathrm{D}_{\mathrm{f}}$ of SCC was above the minimum recommended limit $\left(\mathrm{D}_{\mathrm{f}}>550 \mathrm{~mm}\right)$, some $\mathrm{SCC}$ by analysis of VSI did not present satisfactory stability. These instabilities were confirmed in

Table V - Results of the self-compactability tests and classes in accordance with the NBR 15823:2017 [17, 19-21]. [Tabela V - Resultados de ensaios e classes de autoadensabilidade conforme NBR 15823:2017 [17, 19-21].]

\begin{tabular}{ccccccccc}
\hline Concrete & $\mathrm{D}_{\mathrm{f}}(\mathrm{mm})$ & Class SF & VSI & Class VSI & TFV $(\mathrm{s})$ & Class VF & Box L, H2/H1 (mm) & Class HP \\
\hline CFG12 & 685.0 & $\mathrm{SF}^{\mathrm{a}}$ & 1 & Stable & 22 & $\mathrm{VF}^{\mathrm{d}}$ & 0.50 (block) & \\
CFG19 & 775.0 & $\mathrm{SF}^{\mathrm{b}}$ & 2 & Unstable & $16^{\mathrm{c}}$ & $\mathrm{VF}^{\mathrm{d}}$ & 0.78 (block) & \\
CMG12 & 740.0 & $\mathrm{SF}^{\mathrm{a}}$ & 0 & Highly stable & 12 & $\mathrm{VF}^{\mathrm{d}}$ & 1.0 & \\
CMG19 & 790.0 & $\mathrm{SF}^{\mathrm{b}}$ & 3 & Highly unstable & 6 & $\mathrm{VF}^{\mathrm{e}}$ & 0.50 (block) & One should \\
CFMG12 & 750.0 & $\mathrm{SF}^{\mathrm{a}}$ & 0 & Highly stable & 4 & $\mathrm{VF}^{\mathrm{e}}$ & 1.0 & obtain \\
CFMG19 & 815.0 & $\mathrm{SF}^{\mathrm{a}}$ & 0 & Highly stable & 6 & $\mathrm{VF}^{\mathrm{e}}$ & 1.0 & PL2 $_{0.80}$ \\
CFG12G19 & 790.0 & $\mathrm{SF}^{\mathrm{b}}$ & 2 & Unstable & 4 & $\mathrm{VF}^{\mathrm{e}}$ & $>0.80$ (block) & \\
CMG12G19 & 785.0 & $\mathrm{SF}^{\mathrm{b}}$ & 3 & Highly unstable & 6 & $\mathrm{VF}^{\mathrm{e}}$ & 0.50 (block) & \\
CFMG12G19 & 765.0 & $\mathrm{SF}^{\mathrm{b}}$ & 0 & Highly stable & 6 & $\mathrm{VF}^{\mathrm{e}}$ & 1.0 & \\
\hline
\end{tabular}

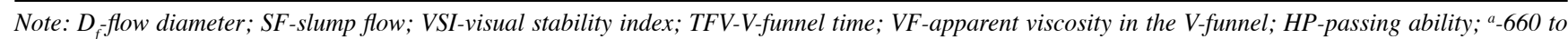
$750 ;{ }^{b}-760$ to $850 ;{ }^{c}$-segregated; ${ }^{d}-9$ to $25 ;{ }^{e}-<9$. 
the L-box test, where these SCC did not meet the passing ability parameter (HP). The SCC that did not meet the HP were GDPCF CFG12, CFG19, CFG12G19 and CMG19, with characteristics of $\mathrm{I}_{\mathrm{v}}<32.0 \%$, DGD and $\mathrm{PCA}=55 \%$, with the exception of CFMG19, with PCA $=50 \%$, that complied with HP. Whereas the SCC with SDPCF (MG12, CFMG12, CFMG12G19), with characteristics of $\mathrm{I}_{\mathrm{v}}>32.0 \%$, continuous distribution and $\mathrm{PCA}=50 \%$ met HP, with the exception of CMG12G19 that showed flow blockage, behavior that may be related to the dosage of PCA $=60 \%$ (Figs. $4 \mathrm{a}$ and $5 \mathrm{a}$ ). It was verified that the concretes with $\mathrm{PCA} \geq 55 \%$ (CFG12, CFG19, CFG12G19, CMG19, CMG12G19) showed instability and blockade, as it can be seen for CFG19 (Figs. 4d and 5d) and CFG12G19 (Figs. 4c and 5c). Whereas the concretes with $\mathrm{PCA}=50 \%$, CMG12, CFMG12, CFMG19 and CFMG12G19 (Figs. $4 \mathrm{~b}$ and $5 \mathrm{~b}$ ), showed no instability and blockade. These facts proved the recommendation of mix-design methods to SCC, whose content of coarse aggregate has to be limited [24]. Therefore, it was evidenced in this study that SCCs with the characteristics of aggregate compositions of SDPCF, continuous distribution and $\mathrm{PCA}=50 \%$ were favorable to obtaining stable mixtures, meeting HP.

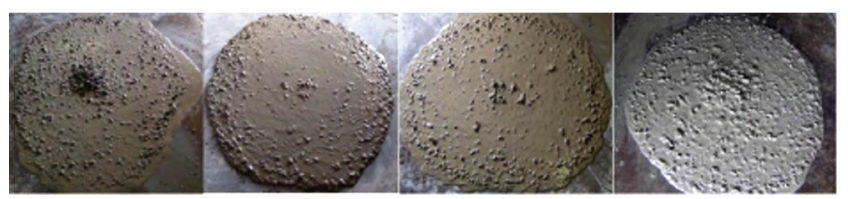

Figure 4: Images of concretes after slump flow test: a) CMG12G19; b) CFMG12G19; c) CFG12G19; and d) CFG19.

[Figura 4: Imagens de concretos após ensaio de slump flow: a) CMG12G19; b) CFMG12G19; c) CFG12G19; e d) CFG19.]
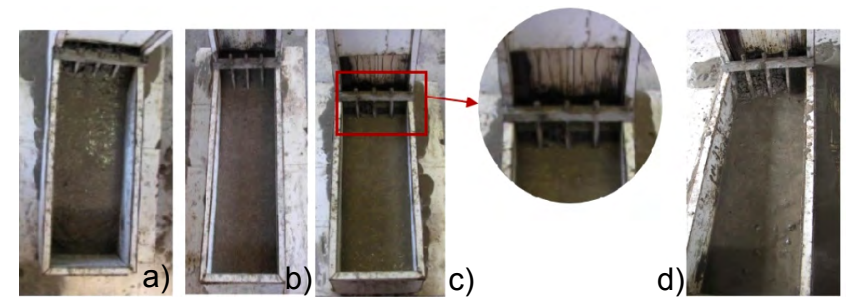

Figure 5: Images of concretes after L-box test: a) CMG12G19; b) CFMG12G19; c) CFG12G19; and d) CFG19.

[Figura 5: Imagens de concretos após ensaio de caixa-L: a) CMG12G19; b) CFMG12G19; c) CFG12G19; e d) CFG19.]

Evaluation of SCC by PPM: the curves of the experimental and theoretical adjustments with the corresponding values of the distribution coefficient (q-value) and coefficient of determination $\left(\mathrm{R}^{2}\right)$, statistical measure, for each concrete are presented in Fig. 6. In Table VI, these coefficients are presented for each concrete mixture. Analyzing the adjusted curves and the values of $\mathrm{q}$ associated to the concretes with binary aggregates composition, it should be noted that in CFG12, CFG19 and CMG19 (Figs. 6a, 6b and 6d, respectively), there was a greater dispersion of data from the experimental grading curves with the curves of the predicted models, resulting in an adjustment to the packing with distribution coefficients of $0.194,0.152$ and 0.126 , respectively, with statistical coefficients of determination $\left(\mathrm{R}^{2}\right)$ of $98.37 \%, 97.89 \%$ and $96.56 \%$, respectively (Table VI), which meant that the adjusted model explained these percentages of the variability in the experimental data. It was observed that the packing of these concretes presented values of q lower than those indicated for SCC, and was related to the packing of mixtures with a greater quantity of fine particles [25, 28, 37]. Regarding the CMG12 (Fig. 6c), there was a smaller dispersion with the theoretical curve of packing with $\mathrm{q}=0.253$, this value within the limits indicated for SCC, with $\mathrm{R}^{2}$ explaining $98.94 \%$ of the observed data. Whereas the concretes with ternary composition CFG12G19 and CFMG19 (Figs. 6e and 6h, respectively) showed greater dispersion of the experimental data with the predicted data, obtaining in the adjustment $\mathrm{q}=0.174$ and 0.184 , respectively, also smaller than the q-value indicated to SCC. The values of the coefficients of determination were equal to $98.50 \%$ and $98.63 \%$, respectively, these being the percentages of model explanation concerning the experimental data. In the case of the ternaries CMG12G19 and CFMG12 (Figs. 6f and $6 \mathrm{~g}$, respectively), values of q were obtained equal to 0.238 and 0.219 , respectively, within the indicated values for SCC, where lower dispersion of the observed data was verified in relation to the predicted data. In these compositions, the coefficients of determination were $98.74 \%$ and $99.06 \%$. Regarding the quaternary CFMG12G19, Fig. 6i, the theoretical packing curve of best fit was obtained with $\mathrm{q}=0.201$, near to those found in the literature for compositions of SCC, with a lower dispersion of the experimental values, with a coefficient of determination $\mathrm{R}^{2}=0.990$, i.e., $99.0 \%$ of the observed data were explained by the model.

Based on non-linear adjustment, it was possible to evaluate that the coefficients of determination achieved values close to $100 \%$, Table VI, which meant that the data variability was explained by the regression model, concentrating on the points of data close to the adjusted regression line. The values of $\mathrm{R}^{2}$ below $98.65 \%$, Table VI, were the ones corresponding to the experimental grading curves of mixtures of concrete that showed higher deviations around the curve of the predicted model. It was verified, therefore, that the coefficient of determination for each type of concrete suffered a direct impact of experimental data in regression analysis. Analyzing Table $\mathrm{V}$ and the results presented in Table VI, no significant differences between the experimental grading curves and the predicted ones were notorious. These differences showed the limitations of both experiments, due to the number of sieves used and the size of the aggregates obtained, as well as the theoretical model, which is based on spherical particles and does not take into account the various characteristics present in the aggregates for concrete. According to the results, the q-value varied with the influence of finer particles. The higher the content of coarse grains, the lower the q-value obtained. This confirmed the tendency of the modified A\&A model to change the q-value, reducing or increasing, depending on the increase or withdrawal of smaller particles from the mixture, respectively. For the evaluated curves, it was verified that the 

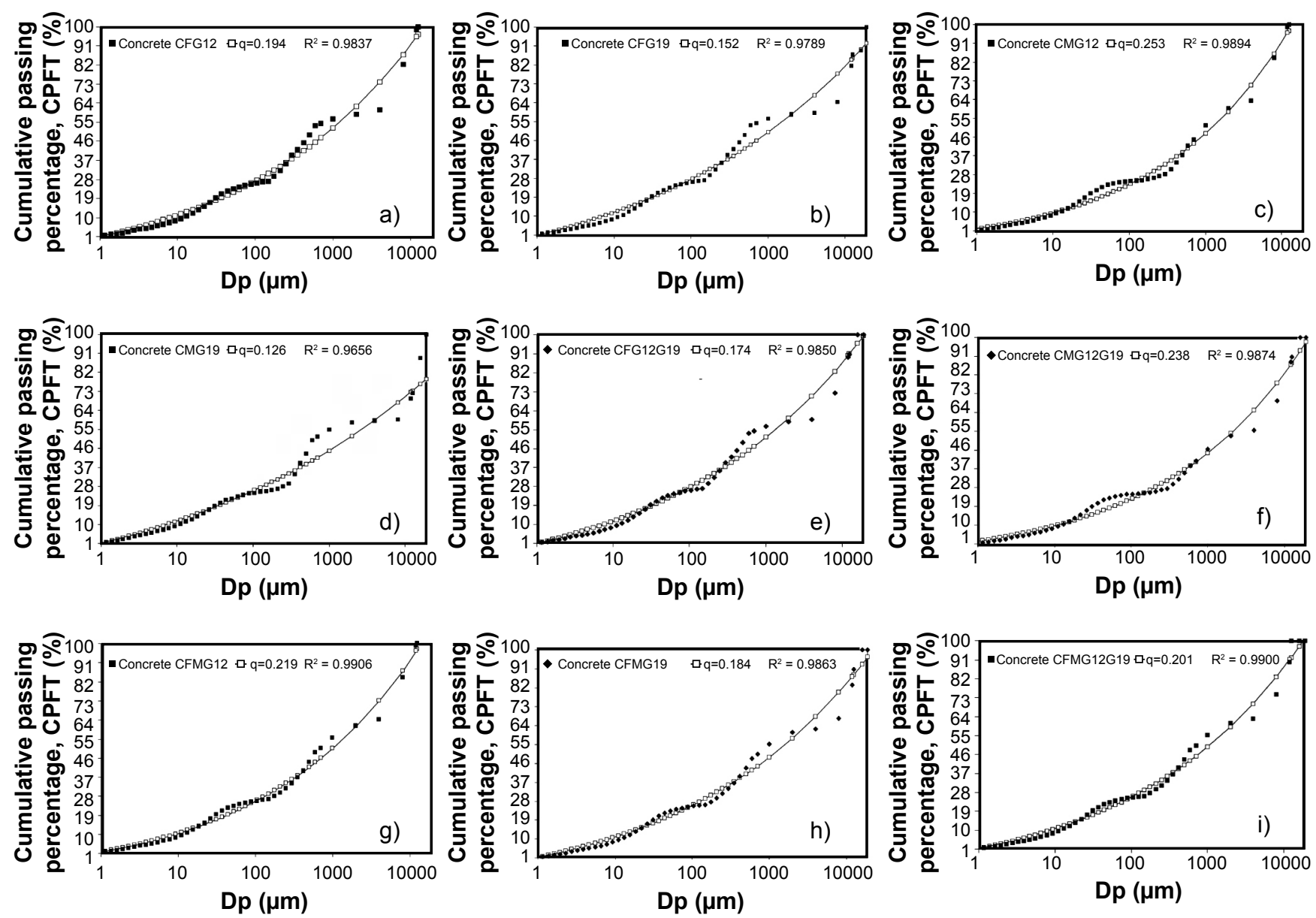

Figure 6: Cumulative particle size distribution curve and coefficients q-value and $\mathrm{R}^{2}$ of non-linear adjustment (Alfred model) for concrete mixture CFG12 (a), CFG19 (b), CMG12 (c), CMG19 (d), CFG12G19 (e), CMG12G19 (f), CFMG12 (g), CFMG19 (h), and CFMG12G19 (i). [Figura 6: Curva de distribuição granulométrica acumulada e coeficientes q e $R^{2}$ do ajuste não linear (modelo de Alfred) para a mistura de concreto CFG12 (a), CFG19 (b), CMG12 (c), CMG19 (d), CFG12G19(e), CMG12G19 (f), CFMG12 (g), CFMG19 (h) e CFMG12G19 (i).]

most accentuated differences of the experimental grading curves occurred in the compositions CFG12, CFG19, CMG19, CFG12G19 and CFMG19, due to the granulometry of coarse particles being concentrated on some intervals of the sieves, and less on CMG12, CMG12G19, CFMG12, and CFMG12G19, showing the best fulfillment of particles in fractions available.

Comparative analysis of the results: the aggregate compositions obtained experimentally by the method of loose unit weight presented distinct characteristics, resulting from granular arrangement itself, but which, in fact, were due to the effectiveness of the used experimental method (O'Reilly [22]). In this method, it is considered that the irregular shape of the grains and the aggregate granulometry were predominant for obtaining the $\mathrm{I}_{\mathrm{V}}$ of each composition, being this parameter indicative of the reached packing. In this study, it was possible to observe that the $\mathrm{I}_{\mathrm{V}}$ was directly related to the difference between coarse and fine particles (DPCF), proving the theory of packing $[7,29,30]$. In addition, the SDPCF belongs to the aggregate compositions with continuous distribution and a lower percentage of coarse aggregate (PCA). These characteristics led to SCC with better mobility, confirming the recommendation of mix-design methods to SCC [2, 4-6, 14]. Finally, analyzing the compositions of SCC by the method of particles packing (PPM) and using the program EMMA and the tool solver, it was possible to determine the distribution coefficient (q-value) and the corresponding $\mathrm{R}^{2}$, both used to evaluate and confirm the packing parameters of compositions of SCC. Therefore, in Table VI, in order to investigate the relationship between the characteristics of packing of aggregate compositions and the SCC, with the parameters of mobility, the data obtained in the different applied methods are exhibited.

Through the results contained in Table VI, it was observed in general that the concretes that presented packing characteristics favorable for obtaining the $\mathrm{SCC}\left(\mathrm{I}_{\mathrm{v}}>32.0 \%\right.$, SDPCF, PCA $=50 \%$, FGD) had the value of $\mathrm{q}$ within the one indicated in the literature for SCC, and coefficients of determination $\mathrm{R}^{2}$ closer to $100 \%$, and complied better the selfcompactability $(0 \leq \mathrm{VSI} \leq 1$ and HP). However, the concretes that presented characteristics of less favorable packing $\left(\mathrm{I}_{\mathrm{V}}\right.$ $<32.0 \%$, GDPCF, PCA $=55 \%$, DGD) to obtain the SCC, the value of q was different from those indicated for SCC and 
Table VI - Packing details of the concretes and aggregates grading distributions and self-compactability parameters. [Tabela VI - Detalhes de empacotamentos de distribuições granulométricas de agregados e de concretos e parâmetros de autoadensabilidade.]

\begin{tabular}{cccccccccc}
\hline Parameter & CFG19 & CFG12 & CFMG19 & CMG19 & CFG12G19 & CFMG12G19 & CMG12G19 & CFMG12 & CMG12 \\
\hline $\mathrm{q}$ & 0.152 & 0.194 & 0.184 & 0.126 & 0.174 & 0.201 & 0.238 & 0.219 & 0.253 \\
$\mathrm{R}^{2}$ & 0.9789 & 0.9837 & 0.9863 & 0.9656 & 0.9850 & 0.9900 & 0.9874 & 0.9906 & 0.9894 \\
$\mathrm{I}_{\mathrm{v}}(\%)$ & 27.6 & 30.1 & 30.9 & 31.3 & 31.9 & 32.1 & 32.6 & 33.6 & 34.7 \\
DPCF & $\mathrm{G}$ & $\mathrm{G}$ & $\mathrm{G}$ & $\mathrm{G}$ & $\mathrm{G}$ & $\mathrm{S}$ & $\mathrm{G}$ & $\mathrm{S}$ & $\mathrm{S}$ \\
PCA $(\%)$ & 55 & 55 & 50 & 55 & 55 & 50 & 60 & 50 & 50 \\
DG & $\mathrm{D}$ & $\mathrm{D}$ & $\mathrm{D}$ & $\mathrm{D}$ & $\mathrm{D}$ & $\mathrm{C}$ & $\mathrm{C}$ & $\mathrm{C}$ & $\mathrm{C}$ \\
$\mathrm{VSI}$ & 2 & 1 & 0 & 3 & 2 & 0 & 3 & 0 & 0 \\
HP & $\mathrm{N}$ & $\mathrm{N}$ & $\mathrm{A}$ & $\mathrm{N}$ & $\mathrm{N}$ & $\mathrm{A}$ & $\mathrm{N}$ & $\mathrm{A}$ & $\mathrm{A}$ \\
\hline
\end{tabular}

Note: G-greater; $S$-smaller; D-discontinuous; $C$-continuous; $N$-non-compliance; A-complied.

$\mathrm{R}^{2}$ less close to $100 \%$, in addition to presenting difficulties in complying with self-compactability $(2 \leq \mathrm{VSI} \leq 3$, and $\mathrm{HP}=\mathrm{N})$. As an exception, the concrete CMG12G19, even with $\mathrm{q}=0.238$, was not favorable to self-compactability (VSI $=3$ and $\mathrm{HP}=\mathrm{N}$ ), being attributed $\mathrm{PCA}=60 \%$, percentage outside RP generally applied to SCC, which destabilized the concrete and led to the blockage. Another exception was CFMG19, which even in favor of self-compactability (VSI $=0$ and $\mathrm{HP}=\mathrm{A})$ did not meet the parameters of packing suitable for $\operatorname{SCC}\left(\mathrm{q}=0.184, \mathrm{I}_{\mathrm{v}}<32.0 \%\right.$, GDPCF, DGD), being attributed to $\mathrm{PCA}=50 \%$, usually indicated to SCC. Therefore, the analysis of comparison of different parameters proved that the PCA around $50 \%$ favors a better performance of SCC, and confirmed what has been generally recommended and found in the literature for the dosage of coarse aggregates in the formulation to SCC [2, 4, 5, 23, 24]. Since it is a concrete that requires a greater cement paste volume, it was concluded that the continuous distributions were the most indicated. Thus, there was a contradiction between the highest voids index and the best packing. In the continuous distributions, it was seen that, for a smaller difference between the particles of coarse and fine aggregates, SDPCF (for example, the composition CFMG12G19), the dosages of concrete tended to be more uniform and mixtures with theoretical grading curve on the q-value between 0.201 and 0.253 ; unlike the discontinuous which had a greater difference between the sizes of coarse and fine aggregates, GDPCF (for example, the composition FG12), the dosages of concrete tended to be more unstable and with grading curve predicted for $\mathrm{q}$ between 0.126 and 0.194 .

\section{CONCLUSIONS}

In this study, an experimental investigation on how aggregate gradations showed different behaviors when employed in dosages of SCC was demonstrated. According to the results obtained from this survey, the conclusions are as follows: i) the value of void content $\left(I_{V}\right)$ was influenced by both the difference between the largest and smallest sizes of particles as well as the aggregate particle size distribution, that is, smaller $I_{v}$ in general occurred in the compositions with the greatest difference in size between particles of coarse and fine aggregates (GDPCF), and the largest $\mathrm{I}_{\mathrm{v}}$ occurred in compositions with smaller particle size difference between coarse and fine aggregates (SDPCF); ii) the absence of intermediate particle aggregates between fine and coarse aggregate (M and G12, respectively) showed high interference in the grading curve of aggregate compositions, being characterized as discontinuous granulometric distribution. These compositions defined as GDPCF had a greater tendency to discontinuity, and the compositions with SDPCF were characterized as continuous granulometric distributions; iii) concretes with compositions that presented lower $\mathrm{I}_{\mathrm{v}}$, GDPCF and discontinuous distributions, in general, did not meet the parameter of passing ability and presented instability caused by excess paste. These concretes induced that a smaller volume of paste would be sufficient for filling of void content and self-compactability. The same occurring in mixture with a larger coarse aggregate volume, which did not comply with the reference parameters (RPs) commonly found in the literature for dosages of SCC. In general, continuous distribution, approaching the diameters of fine and coarse aggregates, that is SDPCF, and aggregate proportion with $50 \%$ of coarse aggregate had appropriate behavior of fresh properties as SCC. Such findings were identified from the analysis of the visual aspect of concretes, in compliance with the visual stability index (VSI) criterium recommended by standard NBR 15823-2:2017, confirming the results of compliance and non-compliance to the concrete self-compactability, as well as to the parameters RPs, DPCF and PCA (percentage of coarse aggregates); iv) on the numerical analysis by particle packing model (PPM) through spreadsheets, for the determination of the q-values of Alfred model, it was realized that minor deviations of granulometric curves of mixtures occurred in continuous distributions; regarding the discontinuous ones, besides presenting deviations along the curve, the concrete mixtures had a greater coarse aggregate volume, which compromised the self-compactability requirements, presenting noncohesive mixtures and segregation, being precisely to 
those with q-value between 0.126 and 0.194 . In general, the distribution coefficients between $0.201 \leq \mathrm{q} \leq 0.253$ were determined in the SCC; and v) concretes with aggregate gradation of greater $\mathrm{I}_{v}, \mathrm{SDPCF}$, continuous distributions and with $50 \%$ of coarse aggregate were more favorable to obtaining SCC, noting a tendency of approximation of the coarse and fine grains in the formulations of the granular skeleton to SCC, distancing from a maximum packing.

\section{ACKNOWLEDGMENTS}

To CAPES - Coordenação de Aperfeiçoamento de Pessoal de Nível Superior, for the scholarship; to FAPEAL - Fundação de Amparo à Pesquisa do Estado de Alagoas for the support and incentive to the scientific research development; to PPG Materials; the authors are thankful to BASF Construction Chemicals Brazil Ltd for providing the admixtures for the experimental program; to the projects Universal and PROCAD/Casadinho; to the group MECOEFICON/UFAL for the involvement and participation of Professors and scientific initiation students.

\section{REFERENCES}

[1] P. Ghoddousi, A.A.S. Javid, J. Sobhani, Constr. Build. Mater. 53 (2014) 102.

[2] H. Okamur, K. Ozawa, Struct. Eng. Int. 6, 4 (1996) 269.

[3] P. Billberg, "Self-compacting concrete for civil engineering structures: the Swedish experience", S.C.C.R.1 (1999).

[4] P.C.C. Gomes, R. Gettu, L. Agulló, L. Bernard, in $2^{\text {nd }}$ Int. Symp. Self-Compact. Concr., Tokyo (2001) 377.

[5] P.C.C. Gomes, R. Gettu, L. Agulló, L. Bernard, Cem. Hormigón 832 (2002) 30.

[6] B.F. Tutikian, M. Pacheco, Rev. Ibracon Estrut. Mater. 5, 4 (2012) 500.

[7] F. De Larrard, in $3^{\text {rd }}$ Rilem Int. Symp. Rheology Cement Suspens. Fresh Concr. (1999).

[8] A.W. Saak, H.M. Jennings, S.P. Shah, ACI Mater. J. 94, 6 (2001) 429.

[9] N. Su, K.-C. Hsu, H.-W. Chai, Cement Concr. Res. 31, 12 (2001) 1799.

[10] Ö. Petersson, P. Billberg, B.K. Van, in Int. Rilem Conf. Product. Methods Workab. Concr., P.J.M. Bartos, D.L. Marrs, D.J. Cleand (Eds.), E\&FN Spon (1996) 483.

[11] P.C.C. Gomes, A. Barros, Métodos de dosagem de concreto autoadensável, Pini, S. Paulo (2009).

[12] H.J.H. Brouwers, H.J. Radix, Cement Concr. Res. 35, 11 (2005) 2116.

[13] E.M. Lisboa, P.C.C. Gomes, F.B. Lima,A.S.R. Barboza, R.M. Lameiras, in X Enc. Nac. Tecnol. Amb. Constr. (2004). [14] K.A. Melo, A.M.P. Carneiro, Constr. Build. Mater. 24 (2010) 1529.

[15] B.L. Damineli, R.G. Pileggi, V.M. John, Ibracon Struct. Mater. J. 10, 5 (2017) 998.

[16] E. Rozière, S. Granger, P. Turcry, A. Loukili, Cement Concr. Comp. 29, 8 (2007) 626.
[17] NBR 15823-1, "Concreto autoadensável - parte 1: classificação, controle e aceitação no estado fresco", Ass. Bras. Norm. Técn., Rio Janeiro (2017).

[18] EFNARC, "The European guidelines for selfcompacting concrete: specification, production and use" (2005).

[19] NBR 15823-2, "Concreto autoadensável - parte 2: determinação do espalhamento e tempo de escoamento método do cone de Abrans", Ass. Bras. Norm. Técn., Rio Janeiro (2017).

[20] NBR 15823-4, "Concreto autoadensável - parte 4: determinação da habilidade passante - método da caixa-L", Ass. Bras. Norm. Técn., Rio Janeiro (2017).

[21] NBR 15823-5, "Concreto autoadensável: parte 5: determinação da viscosidade -método do funil V", Ass. Bras. Norm. Técn., Rio Janeiro (2017).

[22] V. O'Reilly Dìaz, Método de dosagem de concreto de elevado desempenho, Pini, S. Paulo (1998).

[23] R.S. Monteiro, P.C.C. Gomes, K.A. Melo, in IV Congr. Ibero-Am. Betão Auto-Compact., BAC2015 (2015) 205.

[24] P.C.C. Gomes, Optimization and characterization of high-strength self-compacting concrete, UPC (2002).

[25] A.L. Castro, J.B.L. Liborio, V.C. Pandolfelli, Cerâmica 55, 335 (2009) 233.

[26] B.M. Toralles-Carbonari, "Estudio paramétrico de variables y componentes relativos a la dosificación y produción de hormigones de altas prestaciones", Tesis Doct., Esc. Tècn. Super. D'Enginyers, UPC, Barcelona (1996).

[27] A.M.P. Carneiro, M.S. Barata, J.M. Lima, G.L. Quaresma, in $9^{\circ}$ Simp. Int. Inic. Cient. (2001).

[28] I.R. Oliveira, A.R. Studart, R.G. Pileggi, V.C. Pandolfelli, Dispersão e empacotamento de partículas: princípios e aplicações em processamento cerâmico, Fazendo Arte Ed., S. Paulo (2000) 224.

[29] X. Chateau, in "Understanding the rheology of concrete", N. Roussel, Woodhead Publ., France (2012).

[30] H. Moosberg-Bustnes, B. Lagerblad, E. Forssberg, Mater. Struct. Construct. 37, 266 (2004) 74.

[31] P. Goltermann, V. Johansen, L. Palbol, ACI Mater. J. 94, 5 (1998) 435.

[32] O.G. Bolivar, "Disenõ de mezclas de hormigón: métodos empíricos y analíticos", Colômbia (2004).

[33] C. Vogt, "Ultrafine particles in concrete: influence of ultrafine particles on concrete properties and application to concrete mix design", Thesis, Royal Inst. Technol., Stockholm (2010).

[34] F.S. Ortega, R.G.Pileggi, P. Sepúlveda, V.C.Pandolfelli, Cerâmica 43, 283-284 (1997) 183.

[35] R.D. Vanderlei, "Análise experimental do concreto de pós reativos: dosagem e propriedades mecânicas", Tese Dr., USP, S. Carlos (2004).

[36] L. Londero, A. Lenz, Í.M.R. Santos, N.S. Klein, Cerâmica 63, 365 (2017) 22.

[37] M.N. Mangulkar, S.S. Jamkar, Int. J. Sci. Eng. Technol. 4, 5 (2013) 143.

[38] I.S.G. Cavaliere, R.S. Campos, M.P. Barbosa, A.L. Castro, in $58^{\circ}$ IBRACON (2016) 1. 
[39] NBR NM 45, "Agregados: determinação da massa unitária e do volume de vazios", Ass. Bras. Norm. Técn., Rio Janeiro (2006).
[40] V. Roubtsov, "EMMA user guide", http://emma. sourceforge.net/userguide_single/userguide.html.

(Rec. 26/10/2018, Rev. 24/01/2019, Ac. 08/03/2019) 